\title{
Sociohistorical technology studies
}

Citation for published version (APA):

Bijker, W. E. (1994). Sociohistorical technology studies. In Handbook of Science and Technology Studies (pp. 229-256). SAGE. https://doi.org/10.4135/9781412990127.n11

Document status and date:

Published: 01/01/1994

DOI:

10.4135/9781412990127.n11

Document Version:

Publisher's PDF, also known as Version of record

\section{Please check the document version of this publication:}

- A submitted manuscript is the version of the article upon submission and before peer-review. There can be important differences between the submitted version and the official published version of record.

People interested in the research are advised to contact the author for the final version of the publication, or visit the DOI to the publisher's website.

- The final author version and the galley proof are versions of the publication after peer review.

- The final published version features the final layout of the paper including the volume, issue and page numbers.

Link to publication

\footnotetext{
General rights rights.

- You may freely distribute the URL identifying the publication in the public portal. please follow below link for the End User Agreement:

www.umlib.nl/taverne-license

Take down policy

If you believe that this document breaches copyright please contact us at:

repository@maastrichtuniversity.nl

providing details and we will investigate your claim.
}

Copyright and moral rights for the publications made accessible in the public portal are retained by the authors and/or other copyright owners and it is a condition of accessing publications that users recognise and abide by the legal requirements associated with these

- Users may download and print one copy of any publication from the public portal for the purpose of private study or research.

- You may not further distribute the material or use it for any profit-making activity or commercial gain

If the publication is distributed under the terms of Article $25 \mathrm{fa}$ of the Dutch Copyright Act, indicated by the "Taverne" license above, 
have been employed to defend this part of the Dutch coast. But who can guarantee that tonight will not be the 1 night in 4,000 when the sea sweeps over the dikes again?

\section{INTRODUCTION}

Technology and coastal engineering make it possible for some 10 million Dutch to live below sea level behind dikes. Without this technology, there would have been no Netherlands. Technology thus plays in this instance as in others a crucial role in constituting modern society. It seems pertinent to try to understand how technology can play such a role, how it influences society, how it develops, how it-in turn-may be controlled. This chapter will review studies that have aimed to do this. It will also say, by way of illustration, something about the dike-building technology that the Dutch have used to defend their coast against the sea.

In this chapter I will focus primarily on sociological studies of technology, thereby neglecting several other important bodies of literature. First, there is the history of technology. For a comprehensive review of, especially, the American work in this field, see Staudenmaier (1985). Troitzsch and Wohlauf (1980) provide an introduction to the German tradition. The second body of work, which is only briefly mentioned, is the economics of technical change. (But see also the chapter by Michel Callon in this volume.) The state of the art is represented by Dosi, Freeman, Nelson, Siverberg, and Soete (1988). Neither shall I discuss the emerging approaches in rhetorical and linguistic analyses of technology, nor shall I review the philosophical studies of technology. It is important to reestablish the links to philosophical studies (Winner, 1991). A central series of publications for this field is the various volumes of Research in Philosophy and Technology (edited by Paul T. Durbin). A good introduction is provided by Rapp (1981), and Mitcham (1980) gives a comprehensive history and bibliography. Anthropology and archeology are potentially relevant but they are not covered in this chapter.

I have not chosen a disciplinary or chronological review but a thematic ordering - technology's impact, modeling the development of technology, sociotechnical ensembles, controls, and intervention. In also presenting a picture of technology using Dutch coastal engineering, I shall be concerned to ask: How is life at the technological front? What are the activities of engineers and technicians? How is technology shaped and thereby how is society built?

It is a chutzpah to try neatly to define complex concepts such as "technology," "science," and "society" in a handbook like this. I shall therefore restrict myself to stressing the broadness of the word technology as I will use 
have been employed to defend this part of the Dutch coast. But who can guarantee that tonight will not be the 1 night in 4,000 when the sea sweeps over the dikes again?

\section{INTRODUCTION}

Technology and coastal engineering make it possible for some 10 million Dutch to live below sea level behind dikes. Without this technology, there would have been no Netherlands. Technology thus plays in this instance as in others a crucial role in constituting modern society. It seems pertinent to try to understand how technology can play such a role, how it influences society, how it develops, how it-in turn-may be controlled. This chapter will review studies that have aimed to do this. It will also say, by way of illustration, something about the dike-building technology that the Dutch have used to defend their coast against the sea.

In this chapter I will focus primarily on sociological studies of technology, thereby neglecting several other important bodies of literature. First, there is the history of technology. For a comprehensive review of, especially, the American work in this field, see Staudenmaier (1985). Troitzsch and Wohlauf (1980) provide an introduction to the German tradition. The second body of work, which is only briefly mentioned, is the economics of technical change. (But see also the chapter by Michel Callon in this volume.) The state of the art is represented by Dosi, Freeman, Nelson, Siverberg, and Soete (1988). Neither shall I discuss the emerging approaches in rhetorical and linguistic analyses of technology, nor shall I review the philosophical studies of technology. It is important to reestablish the links to philosophical studies (Winner, 1991). A central series of publications for this field is the various volumes of Research in Philosophy and Technology (edited by Paul T. Durbin). Agood introduction is provided by Rapp (1981), and Mitcham (1980) gives a comprehensive history and bibliography. Anthropology and archeology are potentially relevant but they are not covered in this chapter.

I have not chosen a disciplinary or chronological review but a thematic ordering-technology's impact, modeling the development of technology, sociotechnical ensembles controls, and intervention. In also presenting a picture of technology using Dutch coastal engineering, I shall be concerned to ask: How is life at the technological front? What are the activities of engineers and technicians? How is technology shaped and thereby how is society built?

It is a chutzpah to try neatly to define complex concepts such as "technology," "science," and "society" in a handbook like this. I shall therefore restrict myself to stressing the broadness of the word technology as I will use 
it in this chapter. Technology will have at least three different layers of meaning: physical artifacts (such as dikes), human activities (such as making the dikes), and knowledge (such as the know-how to build dikes and the fluid dynamics used to moder them in the laboratory). Additionally, I will consider the word technology to apply not only to hardware technology (such as fascine mattresses) but also to "social" technology (such as the traditional dike management system used in the Netherlands).

This way of talking about technology cuts across the traditional distinctions between such words as technique,technics; and technology. (In French, German, and Dutch, such distinctions are used more coherently. In English, technics is equivalent to hardware; technique is associated with methods, skills, routines, and also with concrete instruments; and technology has two quite different meanings-first, the science of technics and techniques, and, second, the advanced science-based organizational system of technics and techniques [Rapp, 1981; Winner, 1977]). The first practical reason to provide these definitions is that, over the last two decades, most authors have indiscriminately used the word technology to cover all of these meanings and it would be rather pedantic to try to rephrase their work in the more differentiated, older terminology. The second substantial reason is that such distinctions seem to be rather spurious anyway. Where such distinctions seem to hold, they are the result of technologists' work rather than being based upon intrinsic properties of the technologies themselves. A dike is technics (hardware) constructed with a well-determined clay-sand-stone structure to withstand specific forces; it is also a technique (method) to keep out water; and, finally, it is a technology (organizational system) combining mattresses, sand, stones, sluices, measuring equipment, surveillance procedures, and management schemes. Which of these three dikes is the "right" one will depend on the questions asked. A way of defining technology that does not compel us to make a priori distinctions, but instead allows us to trace how actors make various distinctions, thus seems more fruitful. I shall return to this issue later.

Before continuing, I shall introduce some of the salient aspects of "coastal engineering and dike building technology" by briefly presenting the case of the 1953 Netherlands "Flood Disaster." This section is mainly based on published reports, eyewitness accounts, and interviews. See Veen's (1962, pp. 170-200) last chapter (under the pseudonym of Cassandra) for an eyewitness account in English by one of the leading Dutch engineers. Also in English is The Battle of the Floods (1953).

\section{The 1953 Flood Disaster}

A flood in the low countries of the Netherlands is different than floods in other parts of the world. When a storm flood breaks through ordinary 
seawalls, the salt water, after having done its often devastating damage, will return to the sea when the storm is over. This is not so in the Netherlands: Because the country is below sea level, the sea will not retreat at all. On the contrary, the tides will continue to run in and out through the gaps in the dikes, thereby further widening them every 6 hours. The technology and costs to reclaim such inundated lands are comparable to those for making completely new polders. (A polder is an area of land below sea level, created by building dikes around it and then pumping the water out. Some $40 \%$ of the Netherlands consists of polders, varying in size from only a few to many thousands of square miles.) The costs of reclamation of the most difficult parts that were flooded in 1953 were about five times as high as the ordinary selling price per acre. Viewed from a narrow economic standpoint, this is ludicrous.

In early Sunday morning, February 1, 1953, the radio warned: "Many dikes have been damaged. All soldiers on leave have to return immediately. There is a special danger at Ouderkerk. There is a wide breach at Ouderkerk." The dike on the river Rhine at Ouderkerk formed crucial protection for central Holland and its cities, such as Rotterdam, Delft, the Hague, Leiden, Gouda, and Amsterdam (see Figure 11.1). That central Holland was, nevertheless, not flooded was due to a combination of the quick reaction of a skipper and the existence of some of the small old dikes remaining from the network that had been woven through the Netherlands in earlier centuries. A small vessel navigating on the river near Ouderkerk in the early morning was steered into the breach, then 7 meters wide. She was grounded just in front of the breach on the dike's threshold; citizens and soldiers then filled the gap with sandbags and blocks of concrete waste. Before nightfall, the breach had been closed and central Holland saved. (This event emulates the mythical rescue of Holland by Hansje Brinker, an 8-year-old boy who rescued the city of Haarlem and surrounding polders by placing a finger in a hole in the dike when he saw the sea oozing through.) During that day, the old inner dikes held, which was considered by Van Veen (1962) as "sheer undeserved luck" (p. 177). "Undeserved" because engineers had warned the government a long time before that the dikes and sluices were in very poor condition. Van Veen himself, as chief engineer of the Rijkswaterstaat (see below), had been one of the principal spokesmen for upgrading the condition of the Dutch dikes. Almost a year later, on November 6, 1953, the last and largest of the 89 tidal breaches was closed-just before the winter storm season began again.

The whole gamut of technologies that had been developed during centuries of fighting the sea was employed to reclaim the lost land. First of all, time was crucial. Tidal currents quickly widen all gaps. The largest gap in the 1953 disaster was 100 meters wide and 15 meters deep on February 1, but a few months later it had grown to 200 by 20 meters. If the gaps had not been closed before the next winter season, this process of erosion might have been 
irreversible. Also on a scale of minutes, time is crucial. Currents rage at their fastest when gaps are at their smallest. So, the right moment to close off a final gap is in the few minutes of slack water. The age-old technique is to build the dam by working continuously, then close the last gap in the minutes of slack water with a dam, when the water is only a few inches above sea level. (During "slack water," the direction of the tidal current changes from ebb to flood or vice versa.) Later the height can be increased and the dam finished.

For centuries the key material used to strengthen and repair dikes was sandbags. On the night of February 1, 1953, sandbags were made available from emergency depots and played a crucial role. Only since the closure of the Zuiderzee in the 1920 s has boulder clay come to be used to build dikes that are too large for sandbags. The allied invasion of Normandy was made possible by caissons that have increasingly been used to close a tidal gap suddenly and to build the basic structure of the dike. A caisson is a large floating structure, often made of concrete, that is towed into the right position and then sunk onto the sea bed to form the skeleton of a breakwater or dike. Since the 1920s huge supplies of "unpacked" sand, dredged or sucked from the sea bottom, has been used to strengthen the framework of a dike. More recently (in the 1960s) huge blocks of concrete have been employeddumped by special ships, from cable trains, or even from helicopters.

In 1953, as in the centuries before, human power was the energy source that did most of the work. This was the only power source that was distributed widely enough throughout the Dutch coastal area to act adequately at short notice. The sacks were transported by human chains and dumped in the right positions. For the final closures of the 1953 breaches, motor dredges, tugs, ships, and cranes were used, but on that 1953 February night it was human power that saved the day.

An armored foundation is necessary to build a dike in a gap with tidal currents - the natural seabed of sand will not do as it will be scored away, resulting in the undermining of the dike. For centuries, fascine mattresses have been used for this foundation. Such a mattress consists of a net structure about 20 centimeters thick, some 100 meters long, and 20 meters wide. A series of such mattresses is lowered onto the seabed to provide a foundation for the dike to be built upon. Until the 1970 s, when synthetic mattresses were used for the first time for large tidal closures, dikes in the Netherlands (and on all sandy coasts throughout the world) were built on hand-woven mattresses made from branches of willow (or similar) trees. After the mattresses have been prefabricated on land, they are towed out to sea, where they are sunk by the careful dumping of quarry stone on them. This used to be done by hand to guarantee a gradual and controlled lowering into the right position. 
Scientific research started to play a role in the 1920s: The physicist Lorentz was asked to make mathematical predictions about the tidal effects caused by a closure of the Zuiderzee. Hydraulic research received a boost during World War II when it was called upon to investigate the conditions under which harbors could be built for the invasion of Normandy. Empirical research with scale models had already started in the 1930s but was intensified immediately after the war. Suchscale-models played a crucial role in the closure of the last gap in the 1953 disaster. The closure with caissons was carried out some hundred times beforehand in the scaled-down reality of the laboratory. The engineers did not have much "real life" experience with these caissons. Researchers using force-measuring instruments held the cables and acted as tugboats holding the last caisson in place to plug the gap. To be finished before the tide returned, the tugboats had to start while the flood was still rather strong. On the day of closure, at scale 1:1, the young engineers who had practiced in the laboratory were standing on deck behind the old experienced tugboat captains. When one of the cables snapped and control of the caisson was about to be lost, they intervened because they had seen that snapping rope a dozen times and had worked out a scenario to save the caisson. With a series of unusual commands, they took advantage of the queer characteristics of the currents they had discovered in the lab. The last caisson was eased down into the final gap during the crucial few minutes of slack water, and the breach was closed. (Research using modeling is no guarantee for success. For one thing, it depends on whether you have modeled all relevant aspects. Though the Zierikzee closure first seemed a success, a few days later the caissons started to shift. Because the engineers had not wanted to lose the time necessary to lay a fascine mattress foundation, the ground was too slippery and the caissons were pushed out of the gap.)

\section{TECHNOLOGY'S IMPACT}

The first theme of technology studies to be discussed is the impact of technology. Technology's effects on society and nature are so ubiquitous that they frequently become invisible. In public discussions about the closure of the Zeeland tidal inlets in the 1970s, for example, it was often argued that "technology is destroying nature." In the Netherlands, however, as in many" other densely populated areas of the world, "nature" is nothing more than an environment created by previous technologies. If it were not for a variety of coastal engineering technologies, Dutch society and nature simply would not exist. God created the world, but the Dutch made Holland! 
The effect of technology on society is one of the oldest themes in technology studies. A classic case is the alleged effect of the stirrup in establishing feudal society (White, 1962). The stirrup, according to White, effectively welded horse and rider together into an unprecedented fighting force. The maintenance of such military technology, however, required large investments in men, horses, and equipment-investments that could only be made after a fundamental reorganization of society. (See, however, Hilton \& Sawyer, 1952, for a critical review of this claim.) Another example of such an approach is Giedion's (1948) plea for "anonymous history," by which he meant an empirical inquiry "into the tools that have molded our present-day living": locks, bread-baking technology, furniture, household technology, bathing equipment.

Marx's analysis of technology as affecting the forces of production and thus determining society in general presents a similar claim. (See Marx's Das Kapital, 1867.) MacKenzie (1984) has argued for the continuing relevance of Marx's analyses of the machine; the article also provides a comprehensive bibliography. MacKenzie, though, shows that Marx cannot be classified as a simple technological determinist (see below). (See also Bimber, 1990.) In addition to Marx, only a few other economists-all outside neoclassical economics-have considered technology's impact on society. Within neoclassical economics, technology is considered to be important but it is taken for granted that technological innovations are always unproblematically available, "off the shelf." Neoclassical economic models try to capture the influence of specific labor, capital, and technical changes on economic growth. Technology itself, however, stays outside of the analysis - an exogenous variable. This work consequently does not contribute to a specific understanding of the impact of technology on society. The factor technical change is "a rag-bag for all social, managerial, structural, educational, political, psychological and technological changes other than the purely quantitative increase in the volume of labor and capital" (Freeman, 1977, p. 244). Next to Marx, Schumpeter $(1934 / 1980,1939,1942 / 1975)$ has been the most influential economist to have analyzed the role of technology. (See Hagedoorn, 1989 , for an introduction to early economic technology studies and their relevance for modern work.) For Schumpeter, radically new innoyations could create completely new industries and thus lead to new economic and societal directions. In his earlier work, he assumed these innovations to be available off the shelf-technology was still an exogenous variable. In his later work, technology became an endogenous variable when he analyzed the role of the entrepreneur in creating innovations. Schumpeter's position has been labeled "technology push" and the opposed view as "demand pull"-increases in inventive activity respond to increases in demand. 
(Schmookler, 1966, is the locus classicus for this hypothesis. Many empirical studies were carried out to settle this issue of demand pull versus technology push. See Coombs, Savioti, \& Walsh, 1987, and Rosenberg, 1982, for reviews and critique.) This situation changed around 1980 when economists no longer accepted this dichotomy and started to find ways of analyzing technology as an endogenous variable. Examples are Rosenberg $(1976,1982)$, Freeman $(1977,1982)$, Nelson and Winter (1977), Dosi (1984), Coombs et al. (1987), Clark and Juma (1987), Hagedoorn (1989), and the work reported in Dosi et al. (1988). Blume (1992) addresses similar issues from a sociological starting point.

Another fairly general analysis of technology's impact is given by Mumford (1964) in his categorization of technologies as authoritarian versus democratic. Much of Mumford's work can be understood, retrospectively, as underpinning his claim that these two types of technology have recurrently existed side by side since neolithic times-"the first system-centered, immensely powerful, but inherently unstable, the other man-centered, relatively weak, but resourceful and durable" (Mumford, 1964, p. 6). He warns against the hold that distributed technologies exert over all members of society: "Our system has achieved a hold over the whole community that threatens to wipe out every other vestige of democracy." According to Mumford, it does so in a much more subtle way than previous forms of overtly brutal authoritarian technological systems. One important focal point for Mumford has been the city as a technology (see, e.g., Mumford, 1934, 1938, 1961). Mumford (1967, 1970) later extended this analysis of the city into an account of the "megamachine"-an elaborate network of human and nonhuman components used to order the world and to exert power. (For a recent introduction to Mumford's work, see Hughes \& Hughes, 1990.) Ellul (1954/1964) has followed similar lines of argument.

In Mumford's analysis, technological development does have a general political, cultural thrust. In other studies, investigating the impact of technology in more specific terms, the same claim is summarized in the adage "artifacts having politics"; not only does technology have an impact on society, its effects are also strategically directed. Winner (1986b, pp. 19-39) coined this phrase in his 1980 article "Do Artifacts Have Politics?" One of his cases was formed by the bridges over the Long Island parkways. These were deliberately designed by Robert Moses so as to discourage the presence of buses on the parkways leading to the beaches:

Automobile-owning whites of "upper" and "comfortable middle" classes, as he called them, would be free to use the parkways for recreation and commuting. Blacks and other poor people who normally used public transit were kept off the roads because the 12 -foot-tall buses could not pass underneath the bridges. One 
consequence was to limit access of racial minorities and low-income groups to Jones Beach, Moses' widely acclaimed public park. (Winner, 1986b, p. 23)

Whose politics do artifacts have? One specific answer is offered by studies of the labor process. Marx's analysis, in which the capitalist owns the means of production and products while the worker owns her or his labor power, is extended especially by Braverman (1974) in recent "labor process theory." (See also Blackburn, Coombs, \& Green, 1985; Knights \& Willmott, 1988; Noble, 1984; Thompson, 1983; Wood, 1982; Zimbalist, 1979.) The capitalist (and his chief instrument, management) are analyzed as seeking control over the workers' labor power. Following F. W. Taylor's principles of scientific management, the capitalist tries this by deskilling the worker. Technology proves especially useful in this process, according to labor process theory. It enables capitalists to acquire a monopoly over skills and thus to control labor. Much of early German sociology of technology is focused on similar questions. The volume edited by Jokisch (1982) provides a comprehensive overview, which also addresses, in addition to the impact theme, questions concerning the shaping of technology.

How do artifacts acquire their politics? Is it bestowed upon them by their users or is it "baked into them" during their construction? Have the fascine mattresses leaped into existence because of a brilliant inventor, or have they emerged by a slow, gradual accumulation of small improvements? Different kinds of answers have led to considerable bodies of literature to which I shall now turn.

\section{MODELING THE DEVELOPMENT OF TECHNOLOGICAL ARTIFACTS}

In this section I want to discuss three classes of models for the development of technological artifacts-materialistic, cognitivist, and social models. The first class focuses on the technology itself as its explanatory basis, thus stressing the relative autonomy of technological development; the second class consists of evolutionary and rationalistic models, taking technological knowledge as the key characteristic for modeling technology; and the third class finds its starting point in the social practices related to technology and focuses on the social shaping of technology. The three classes of models are to some extent complementary-they stress different but important aspects of the development of technology. In other respects, however, they are contradictory, and I will argue that the models presented below give successively more adequate descriptions of the development of artifacts. They do so because they provide successively better instruments to 
analyze the development of technology in its relations to society. For, if the ultimate goal of sociohistorical technology studies is to understand the interplay between technology and society, those models that explicitly conceptualize (parts of) the relationship between the social and the technical are to be preferred.

Another way of comparing theories of technology is to ask whether they are technologically determinist. Bimber (1990) distinguishes different versions of technological determinism-the "norm-based account" (associated with Jürgen Habermas and Jacques Ellul), the "unintended consequences account" (used by, for example, Langdon Winner), and the "logical sequence account" (most clearly advocated by G. A. Cohen, Richard Miller, and Robert Heilbroner). It is only the latter, Bimber argues, that is both technological and deterministic. I will use the term in this sense. Technological determinism, then, comprises two ideas - technological development is autonomous, and societal development is determined by technology. Following Edgerton (1993), it seems wise for analytical purposes to reserve the term technological determinism only for the second idea, a theory of society. This thesis of technology determining society should then be kept separate from the idea of an autonomous technology, a theory of technology. In practice though, the two views often are held in combination. Technological determinism has become a term of abuse among scholars. Even those who take the view that technological change is the prime mover of socioeconomic change vehemently reject the label. This is probably partly caused by the important ideological role the technological determinist view plays in public and political discussions about technology. There it results in a displacement of causation from human agency to machines, which is detrimental to attempts to create instruments for more democratic control of technology and society. The following models provide successively better tools for avoiding such an autonomous view of technology.

\section{Materialistic Models}

The development of fascine mattresses, especially in this century, seems to provide an ideal example of a technology that "logically" was improved, and thus requires no further explanation for its development. By small steps the production yard where the mattresses were prefabricated was improved; new materials such as polypropylene were used as a substitute for willow branches; mechanization was introduced to fabricate various elements of the mattresses; special ships were constructed for sinking the mattresses by mechanically dumping stones in a controlled way. The apex of this development was the design of a special mattress for use in the Oosterschelde in the 1970 s. Here, a synthetic mattress was manufactured in a specially con- 
structed plant and rolled onto a huge drum that could be picked up by a special ship. The ship was manoeuvred into the right position and the mattress was gradually rolled off and lowered into the sea-as if dwarfs were playing with a gigantic paper toilet roll. Developments in new materials and mechanization provided the impetus for this seemingly "automatic" development.

Most materialistic models that stress an "autonomous logic" of technological development are not very elaborate and often can be found implicitly in much of the work discussed in the previous section on technology's impact. These models are often also technologically determinist. Other models in this materialistic class stress the contingent character of technological development rather than a unilinear logic. Generally these models are evolutionary. An evolutionary model of technology would, first, highlight the variations generated by engineers and others, and then focus on the process by which some of these variations are selected. The fascine mattresses, for example, passed the selection process because in the wet Netherlands there was an abundant supply of willows, and thus for centuries this technology hardly changed. Many innovations in making these mattresses found a niche when after 1953 the demand increased dramatically-a mechanical "spinner" to make a cable of willow branches, an artificial yard to do the weaving without being bothered by the tide, and synthetic materials to substitute for wood. Several of the variations that were invented in the 1950 s would have been possible, from a narrow technical point of view, decades earlier.

Various authors have formulated evolutionary models to get away from the image of the heroic inventor. Ogburn (1945) and colleagues (Gilfillan, 1935a, 1935b; Ogburn, with Gilfillan, 1933; Ogburn \& Nimkoff, 1955) and Usher (1954) are among the earliest of these. They all stress the accumulation over time of small variations that finally yield novel artifacts. Recently, Basalla (1988) has presented an evolutionary theory of technological development that also focuses primarily on the development of technical artifacts. The economic model developed by Nelson and Winter (1977) also falls within this rubric, though the unit of analysis in their model is the firm rather than the artifact. They identify "technological regimes" that capture engineers' beliefs about what is feasible and thus give technological development an explicit place. Their model has some overtones of technological autonomy-they see technology as developing along a "natural trajectory."

\section{Cognitivist Models}

One step away from an autonomous view of technological development is to stress the role of technological knowledge. Such a more cognitivist view of the fascine mattresses development avoids the assumption of a logical (or evolutionary) chain of successive artifacts. Rather than a fairly automatic 
process induced by mechanization and material innovations, or a more contingent process governed by blind variation and selective retention, the cognitivist view stresses the role of problem solving. Mechanization thus was a solution to the increased demand for mattresses for dike foundations; new materials were a solution to the scarcity of willow trees; and preloaded mattresses with fixed ballast were a solution to the problem of sinking mattresses on steep slopes from which the loose ballast stones would have rolled down.

Cönitivist models of technology come in many shapes and forms. They take their starting point in the observation that the most important aspect of technology is technological knowledge (see Laudan, 1984, for a comprehensive review and several contributions to this approach). Some of these models are primarily rationalistic (see, e.g., Vos, 1991). Most, however, try to capture the contingent character of technological knowledge in evolutionary models. (See Elster, 1983, for a discussion of several varieties of models, including the evolutionary one.) Constant (1980) and Vincenti (1990) both find their starting point in D. Campbell's (1974) work, which is part of a large tradition in trial-and-error and variation-and-selection models for the growth of scientific knowledge (see Radnitzky \& Bartley, 1987, for a selection, including Campbell, 1974). Constant (1980), in an analogy to Kuhn (1962/ 1970), distinguishes between normal and radical technological activity. $\mathrm{He}$ then analyzes the development of normal technology by stressing the role of the relevant technological community. Constant identifies the possibility of coevolution of two closely linked but separate technologies that exert powerful mutually selective pressure. He describes the turbojet revolution as a case of coevolution: "New airframes partially defined the evolutionary environment of aircraft piston engines, while creation of the turbojet ultimately would compel a revolution in airframe design and construction" (Constant, 1980 , p. 14). By focusing on the design process, Vincenti (1990) studies the "epistemology of engineering." He identifies six categories of technological design knowledge and subsequently describes several knowledge-generating activities. Finally, Vincenti proposes an evolutionary model to describe the growth of this technological knowledge as a nested hierarchy of blindvariation and selective-retention processes in which the knowledge produced at one level is used in the process at the next outer level.

What is the relationship between science and technology? All technology studies problematize the relationship between science and technology. The old image of technology as being merely applied science was already dismissed in the first STS handbook (Spiegel-Rösing \& Price, 1977)-it is no adequate description of the entanglement of the two (Layton, 1977). Pinch and Bijker (1984) argue for an empirical approach, not assuming a priori any inherent distinction. Vincenti (1990) draws some distinctions between tech- 
nological knowledge and scientific knowledge but grants autonomy to the realm of technological knowledge-it is no longer to be considered an appendage to science.

\section{Social Shaping Models}

The idea that technology is socially shaped, rather than an autonomously developing force in society or a primarily cognitive development, is not entirely new (Mumford, 1934, 1967, for example, argues that sociocultural conditions precede the development of specific technologies), but its present momentum and precise formulation are quite recent. This view is most clearly advocated by MacKenzie and Wajcman (1985). It takes issue with the autonomy view head on. Social shaping models stress that technology is not following its own momentum or a sort of rational, goal-directed, problem-solving path but is instead shaped by social factors.

One early strand of this theme again is inspired by Marx and Braverman. Noble (1984) argues that, in the automation of machine tools, the choice of the numerical-control type over the record-playback type can be understood as the management's social shaping of this technology: The first would allow more control over the workforce than the latter, where highly qualified workers still play a crucial role.

At a more general level, state intervention is a form of social shaping of technology. Military technology is one example where such shaping plays an important role with its direct consequences for electronic, nuclear energy, and transportation technologies. At a similar general level, domestic technology and house building are socially shaped by the gender relations in a society. (See the chapters by Smit and by Wajcman in this volume. MacKenzie, 1990a, uses his analysis of guided missile technology as a platform to contribute to an understanding of sociotechnical development more generally.)

Focusing on the communities of practitioners, the sociological versions of some of the work discussed under the previous heading also contributes to an understanding of the social shaping of technology. In Constant's (1980) analysis, for example, the "community structure of technological practice" plays a crucial role. The primarily economic Nelson/Winter model was first extended by Dosi (1984), who introduced the concept of "technological paradigm." It was then sociologized by Belt and Rip (1987), who added that the variation and selection processes are not independent but linked by a "nexus"- -examples of such nexuses are the patent system and the test departments of large R\&D laboratories.

Pinch and Bijker (1984) have argued that technology studies could benefit from recent social studies of science. In a general methodological argument 
concerning the explanatory tools to be applied to the analysis of technology, they first argue, with Staudenmaier (1985), that, to avoid a Whiggish account of technological development, more attention should be paid to failed technologies rather than exclusively doing the success stories. Then they suggest, with Bloor (1976), that, in analyzing the failure and success of artifacts, the same conceptual framework should be applied. This "principle of symmetry" can be formulated as follows: Do not, in explaining the success or failure of an artifact, refer to the working or nonworking of that artifact as explanation. The working of an artifact is not an intrinsic property from which its development stems but is a constructed property and the outcome of its development.

\section{SOCIOTECHNICAL ENSEMBLES}

Students of technology have not been satisfied with the partiality of the impact and shaping themes. One of the problems of the social shaping thesis is, for example, that there seems to be too little room for the obvious effects of technology on society. Much recent work has been devoted to integrating the impact and shaping themes within one analysis of what $I$ will call "sociotechnical ensembles" (see Law \& Bijker, 1992, for a review of recent work along this line). Before briefly reviewing this work, I will again turn to a coastal engineering case-one that particularly seems to call for such an integrated analysis.

\section{The Deltaplan}

The 1953 disaster in the Netherlands hastened political discussions over the deterioration of the dikes. Did the solution lie in repairing and heightening the dikes or in pursuing more radical options? (Before World War II, Van Veen had actually proposed several plans that included closures of the tidal basins in the Zeeland delta. None of these plans had been discussed very seriously.) On February 18, 1953, a government committee was set up. Its most important report, published in February 1954, recommended a radical solution. Work started unofficially in August 1955, and in 1957 the Dutch Parliament finally followed the committee's advice and opted for the radical solution. A law was passed that specified "the Deltaplan"-all tidal inlets in the Zeeland delta, where the Rivers Rhine and Maas flow into the North Sea, were to be closed except the Westerschelde, connecting Antwerp to the sea, and the Waterweg, connecting Rotterdam to the sea (see Figure 11.1).

This radical choice entailed a partial abandonment of the preexisting decentralized system of dike and water management. The large "high-tech" 
closures of the tidal inlets would come under national jurisdiction rather than under the command of the local water boards. One of the conclusions after the 1953 disaster formulated by the central authority, the Rijkswaterstaat, was that this decentralized control system was partly to blame for the bad quality of some of the dikes. (The Rijkswaterstaat is the national governmental body for water and dike management. Because of its huge size and related political power, it was sometimes called "a state within the state.") Another possible conclusion, though at that time formulated by only a few, was that the decentralized dike management system had provided the crucial skills, knowledge, and technology to react adequately, immediately, and on the spot after dike breaks. In the Deltaplan, coastal protection previously provided by some 1,000 kilometers of dikes under decentralized control was to be taken over by less than 30 kilometers of dikes under centralized control. By the late 1950s, the faith in the Rijkswaterstaat was such that this centralization met with no resistance.

The work proceeded well. It was explicitly set up as a learning processthe "Delta-school." The first project was a flood barrier in the Rhine just downstream of the 1953 breach at Ouderkerk to protect the central region of Holland. (A flood barrier is a structure that normally is open to let the water pass but can be closed in case of a dangerously high tide.) Other projects followed in order of increasing magnitude and complexity. In addition to the four main closures, a series of secondary inland dams and sluices was needed to control the tidal streams during the main closure works and to manage water levels afterward. The four main closures were to be three dikes and one discharge sluice for the water of the Rivers Rhine and Maas. Safety criteria had overriding priority in decisions on the details of the Deltaplan. The buzzword in both political and technical discussions was Delta levelthe water level during a storm surge that had a chance of occurrence in $1: 10,000$ years. Dikes were designed with this level in mind. In design practice, this so-called basic level with a transgression chance of $1: 10,000 \mathrm{did}$ not have the unambiguous hard character it had in the public debate. Various differential factors, among which hydrological coastal variables and an "economic reduction factor," resulted in different design levels along the Dutch coast. The resulting design level for the Zeeland coast was, for example, 1:4,000 years. Flood barriers or sluices to allow the tide to continue were ruled out because these would be too expensive. The Deltaplan would thus create several huge new freshwater lakes without any tidal movement. Though detailed insight into the ecological effects was neither available nor deemed very important, it was explicitly recognized that oyster farms and saltwater fishing would have to be abandoned. This price seemed reasonable enough in the light of the required safety and there was no discussion of it, especially because the freshwater would be beneficial to agriculture in the region. 


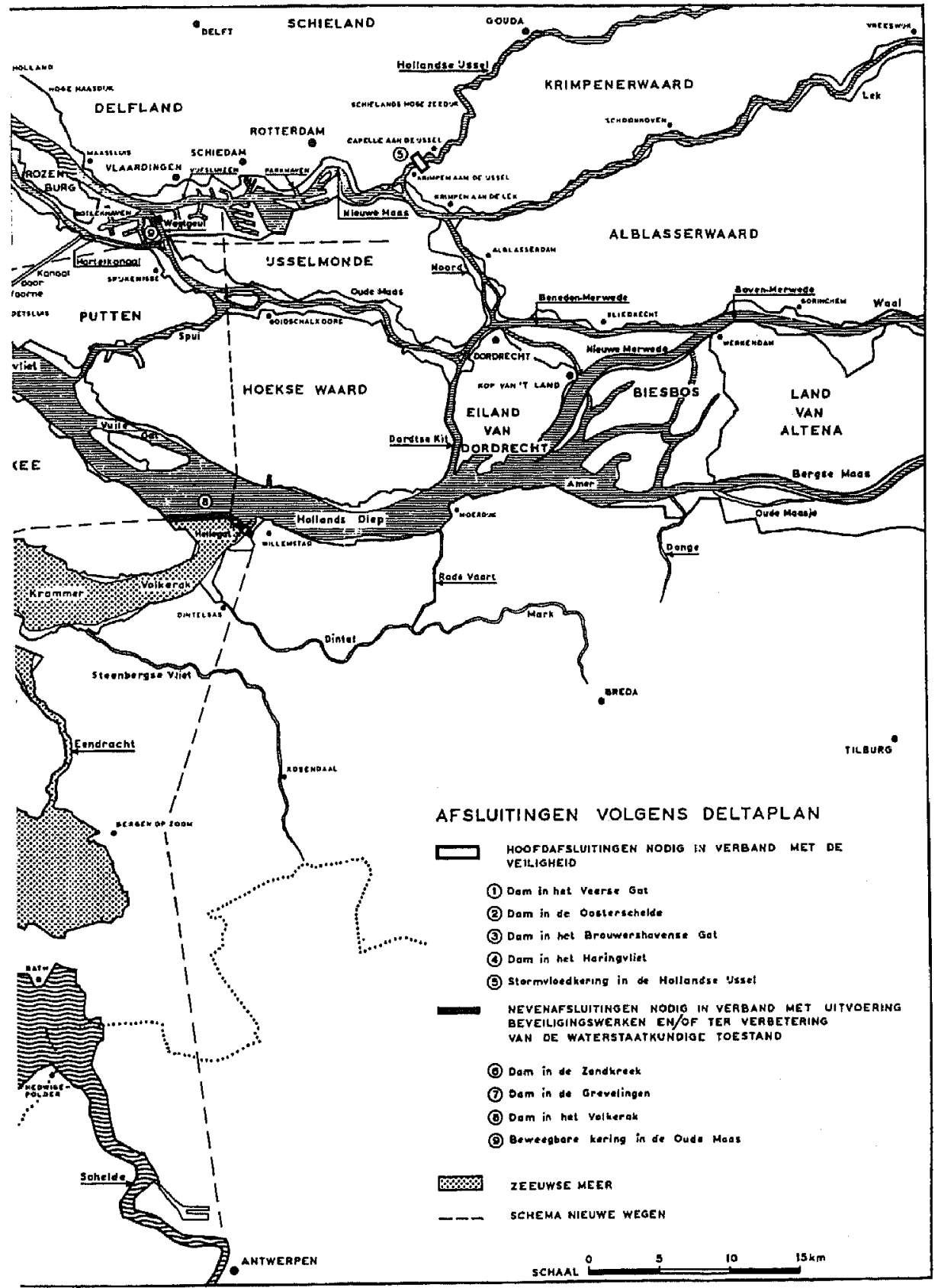


The Deltaplan was generally recognized as a technologically unique project of which the final large closures were well beyond the technical possibilities available in 1953 when the plan was first suggested. But the case was such that work actually began before Parliament had approved the plan. The subsequent parliamentary enactment went very smoothly. This can be taken as a further indication of the nationwide support for the plan, with its safety priority, as well as confidence in the Rijkswaterstaat as the central authority to carry out the plan.

The Deltaplan required not only technological innovations on an unprecedented scale but also organizational and economic innovations. The first director of Rijkswaterstaat's Delta Department attempted to negotiate specific organizational forms that would give him direct access to the responsible minister and would allow him to bypass other competing departments within the Rijkswaterstaat. He succeeded, but only partially. The organizational culture of the Rijkswaterstaat proved to be too intransigent, and he had to live with the existing hierarchical structures. The effects of this failure and the resulting competition between different Rijkswaterstaat departments can be traced "inside" the various technical designs of the Deltaplan. The oversized design of the Haringvliet outlet sluices, for example, was determined by specific evaluations of ice risk. Engineers at different positions in the Rijkswaterstaat made different assessments of this risk. Another organization of the design team might have resulted in smaller gates (H. A. Ferguson, 1988). Other "organizational" innovations included a new hydraulics research department, a new relationship with the Delft Hydraulics Laboratory, the on-site training of young engineers to supplement their theoretical training, and new contract arrangements with the dredging, construction, and mattress production companies. Financial variables played an important role until the very end of the project and can be identified in all designs (see below).

Though the final result of the Delta project, and especially the Oosterschelde barrier, is now advertised as the Eighth Wonder of the World and though its success figures as unambiguous proof of scientific and technological progress in this field, insiders point out how there was no simple accumulation of knowledge. There are still controversies over such seemingly basic issues as the design of the dikes. It was only after the 1953 flood, for example, that engineers realized that dike breaches almost always occur from the dike's inside; water flowing over the top of the dike scores the inner slope and only then does the dike burst. Virtually all efforts at dike building and repair since prehistoric times had been directed toward the outer slope of the dike. Even after research into the 1953 dike breaches, knowledge of dike building was not a set of objective, hard scientific facts. For example, $H$. A. Ferguson (1988) comments on the obvious differences between two of the main Deltaplan closure dikes: 
One may think that these [differences] have been caused by important technical considerations. The reason however is, that the designers could not agree about the benefit of an outside shoulder; in the one case the opponents of the shoulder won and the Veere Dam did not get a shoulder; some time later the proponents won, and the Brouwers Dam got a broad shoulder. We still do not know what is best. (p. 60)

Research using models played a crucial role in carrying out the Deltaplan. Since the 1920 s mathematical models had been used, and since the $1940 \mathrm{~s}$ these were complemented by physical models in which physical dimensions were scaled down by factors of 100 and 400 ; time was scaled up by a factor of 40 ; sand was scaled down by using finely ground Bakelite; and water stayed water at 1:1. (Vertical down scaling, for example, 100:1, cannot be as large as the horizontal down scaling, for example, 400:1, because the water's behavior changes fundamentally when flowing in more shallow streams. This is one example of the complicated scaling laws that are involved in all technological modeling. These scaling laws mean that results from the model cannot be translated into scale $1: 1$ in any unambiguous or "objective" way, just as the results of scientific experiments cannot be taken to provide an unambiguous answer about Nature's state.) The most complicated model of the Oosterschelde used a combination of salt and freshwater. For detailed studies of dikes and structures, wind and wave flumes were used. The organization of this model research was as difficult and crucial as interpreting the scaling laws. Managing the relations between Rijkswaterstaat, the Delft Hydraulics Laboratory, and the private construction firms was thus as much part of the Deltaplan closures as was the weaving of mattresses or the design of the discharge sluices. Most research was carried out by the Delft laboratory, but the translation into design and construction was the Rijkswaterstaat's responsibility. At some point, the private dredging firms also carried out some scale model studies in Delft. Because, for reasons of competition, they wanted to keep these results secret from other firms and the Rijkswaterstaat, the hall in which the models were located was as carefully guarded as any military research facility.

By the end of the 1960s the Deltaplan had been extremely successful and proceeded to its final phase-the closure of the largest tidal basin, the Oosterschelde. The pylons for the cable way that would dump the large concrete cubes for the core of the dike were put in position in 1971. However, the almost nationwide support that the Deltaplan had received in the $1950 \mathrm{~s}$ now started to wear thin. The special quality of the tidal ecology of the Oosterschelde became valued more than before; the unwelcome prospect loomed of the closed estuaries.becoming huge sinks for the polluted waters of the Rhine and Maas; growing attention to the "mountains" of butter and wheat in the European Community lessened the importance of stimulating 
agriculture with new freshwater supplies-food production no longer seemed to be the primary problem it had been immediately after World War II. Also other societal changes in the 1970 s affected the Delta works-the Rijkswaterstaat's authority (as in so many other political institutions in the Netherlands) was disputed. During the general elections in 1972, the Oosterschelde closure became a political issue. The alternative of leaving the Oosterschelde open and increasing the height of all its dikes was proposed. As a result of this debate, the Netherlands were almost torn apart. In Parliament the almost unanimous support for the project from 15 years before was now reduced to only $50 \%$, and some of the coastal engineers were transformed from respected builders of a safer nation into ecology wreckers, even to their own
families.

In 1974 the government decided after resolving a deep internal controversy to close the Oosterschelde with a flood barrier. This would delay for some 7-8 years the finishing of the Deltaplan, and thus the reaching of the "Delta-level" safety criterion of a 1:4,000 years flooding chance. To many, especially in Zeeland, this was an unacceptable risk given that the present dikes had a flooding chance of 1:100 years. In Parliament a motion to continue the complete closure was rejected by 75 to 67 votes. Those who were in favor of closure called this "a purely political decision."

The pylons for the cable way were dismantled and brand-new mattresses were dredged away. Intensive research on the tidal streams and sand bottom started. To increase the safety of Zeeland during the delay period, the dikes were heightened to a flooding chance of 1:500. It soon became clear that the project was of unprecedented complexity. The Oosterschelde bottom was found to be of an unusually fluid sort of sand and the tidal velocities and volumes encountered were larger than in any previous project. One of the consequences was that the flood barrier had to be constructed on the spot, in open water. The only other big mechanical construction for the project-the discharge sluices-had been built in a working polder in the inlet; after completion of the sluices, the polder was flooded, its dikes removed, and the remaining gap between sluices and shore closed with a dike. Such a solution was now impossible because the resulting decrease of tidal volume would irreversibly affect the ecology of the Oosterschelde. Several radically different designs were discussed and tried in model research.

The two main problems turned out to be the foundation of the dam (a shift of only a couple of inches would jam the sliding doors of the dam, reducing the flood barrier to a useless ruin) and control of the budget (Parliament had stipulated maximum costs; if this condition could not be met, the closure had to be made with an ordinary dam). The foundation problem was solved partially by building a new ship that used four 40 -meter-long vibrating needles to condense the seabed, and partially by using prefabricated mattresses that 
were sunk by a specially designed ship with a horizontal and vertical accuracy of a few inches. The budget problem was solved by a combination of measures: a design adaptation in the latest stage (one sliding door less in the barrier), violation of the no-interference-with-ecology principle guring construction (engineers were allowed "to flipper": to close the barfier several times to facilitate works), and creative accounting.

The Oosterschelde flood barrier dam was opened by the queen of the Netherlands on October 4,1986 . This virtually finished the Deltaplan. It was completed some 10 years behind schedule with a budget overrun on the Oosterschelde barrier of $30 \%$. At the same time, this technological system is widely acclaimed to be the crown of Dutch coastal engineering. It is, however, still mistrusted by a few experts because of the unprecedented critical nature of its foundation. In the Deltaplan, as perhaps best illustrated by the Oosterschelde barrier, values of safety and environmental protection are built into the very technologies. But the organization of Rijkswaterstaat, the relationships between dredging firms and laboratories, and the financial politics of the Dutch Parliament are also embedded in the technology-just as much as are mattresses, concrete pillars, steel doors, and control computers. Dutch society shaped the technology of the Deltaplan as much as the Deltaplan shaped Dutch society for the future.

The approaches in technology studies that are to be discussed in this section do not, however, stop here-with this conclusion that the impact of technology on society and the shaping of technology by society are complementary phenomena. There is an additional argument-that even the very distinction between social and technical cannot be made a priori. Is the closure of the Oosterschelde by a flood barrier a technological solution? It certainly is seen as such by most visitors to the dam, engineers and others alike. Or is it a political solution? It certainly was seen as such by important spokespersons of both contesting parties in the late 1970s. Is the Deltaplan a technology to shorten the coastline and thus protect Zeeland against the sea? Or is it a social system that centralizes dike management and thus safeguards Zeeland? When zooming in and analyzing the sociotechnical ensemble of the Deltaplan and the Oosterschelde barrier (or, for that matter, fascine mattresses), it becomes clear that these are not constructed from elements that are a priori and intrinsically social, technical, economic, or cultural. These various elements form a seamless web.

\section{Sociotechnical Ensembles: Three Approaches}

In the 1980s research got under way that analyzed technology and society as an intimately interconnected, heterogeneous ensemble of technical, social, political, and economic elements. There are several approaches that view 
technology in this way. Some themes are common to all the approaches. (Some recent German work defies a categorization in these terms, because it explicitly draws on all of them, and more. See, for example, Hennen, 1992; Joerges, 1988; Rammert, 1990; Weingart, 1989.) Though, for example, not accepting a technological determinist or an autonomous technology view, they all try to account for the apparently obdurate character of many technologies. MacKenzie and Spinardi (1988) differentiate the concept of technological determinism and thus mold it into a more usable concept. Misa (1988) demonstrates how the occurrence of technological deterministic views within technology studies cannot be simply dismissed as an inappropriate usage of the old standard image of technology. He demonstrates how technology studies on a micro level of analysis tend to support the contingent nondeterministic character of technology, while macrostudies tend to produce deterministic images.

O20 The systems approach analyzes technology as heterogeneous systems that in the course of their development-acquire a technological momentum that seems to drive them in a specific direction with a certain autonomy. (See Hughes, 1983, for the fullest presentation of this approach, which is developed in a comparative analysis of the electricity distribution systems in New York, London, and Berlin.) Hughes (1987b) explicitly makes the argument against a priori distinctions between the social, the technical, the scientific, and so on. Shrum (1985b) also studies large technical systems and networks, but from a more sociological perspective, combining qualitative and quantitative methods. The Deltaplan can be considered such a system. It consists of a heterogeneous set of elements such as dikes, flood barriers, channels, lakes, water levels, salt- and freshwater regimes, navigation routes, and rules for closing and opening the sluices and barriers. The social shaping theme is further elaborated by Hughes's identification of national styles in the development of technological systems. In the case of coastal engineering, this 1. would amount to the existence of clear differences between, for example, English and Dutch flood barrier design styles. The concept of "technological momentum" nicely captures the seemingly autonomous nature of technological systems, while at the same time showing that it is not an intrinsic property but is slowly built up during the system's development. Though the approach was developed by analyzing technological systems that are in a physical sense large, such as electricity distribution systems, railway systems, or telephone networks, the approach can be applied to physically small technologies such as missile guidance systems (MacKenzie, 1990a) and space shuttles (Pinch, 1989). The thrust of the research program, however, is still in studying large technical systems (La Porte, 1989; Mayntz \& Hughes, 1988; Weingart 1989). Hughes's specific framework relates to (private) business systems-such as Edison and Siemens as entrepreneurial system builders. 
Also, one of the ways in which these systems build up momentum is through economies of scale. Neither aspect seems directly applicable in the Deltaplan case.

The actor-network approach, associated with Callon, Latour, and Law, describes sociotechnical ensembles as heterogeneous networks of human and nonhuman actors. Clear examples of this approach are Callon (1980, 1981, 1986b), Law (1987a), and Latour (1984, 1987, 1992). For more references, see Law (1986c), Bijker, Hughes, and Pinch (1987), Law (1991c), and Bijker and Law (1992). The development of these networks is analyzed as a concatenation of translations-efforts by actors in the network to move other actors to different positions, thereby translating the meaning of these actors as well. The concept of translation is the crux of the actor-network approach (see the chapter by Callon in this volume). It is used to analyze how an ordering of society is brought about by reshuffling and transforming machines, institutions, and actors. The power of actors (such as a captain of industry, or the Rijkswaterstaat, or a Mafia leader) does not consist of something inherently special in those individuals or institutions but originates from the networks they can control. A characteristic of the actor-network approach, and one by which it can be distinguished from the numerous other network vocabularies in STS studies, is its ontological basis. By not accepting a fundamental distinction between human and nonhuman actors, which is central to Western sociology and indeed to most post-Kantian thinking, the actor-network approach is based on a premodern footing. (See Collins \& Yearley, 1992a, 1992b, and Callon \& Latour, 1992a, for a debate on this foundational question.) A "principle of generalized symmetry" is adhered to: Analyze the human and the nonhuman world with the same conceptual framework; in other words, the explanation of the development of sociotechnical ensembles involves neither technical nor social reductionism. The relevance of this approach to the Deltaplan case will be clear. The case could be described (though I did not attempt this) in a vocabulary that builds anetwork from such diverse actants as engineers, the Rijkswaterstaat, environmentalists, dikes and barriers, oysters, tidal streams, and storm surges. (The actornetwork approach draws on semiotics. By using the term actant, the traditional social science connotations of the word actor are avoided.) An explanation of the development of the Oosterschelde barrier would thus avoid drawing one-sidedly on either "social factors," such as politics finances, or fear, or on "technical factors," such as increased engineering knowledge, better mattresses, or faster computers.

In the social construction of technology approach, Pinch and Bijker (1984) take "relevant social groups" as their starting point. (This "SCOT" approach originally appeared under the banner of "social shaping of technology." After some hesitation, I have decided to present it here, in the section 
about sociotechnical ensembles, because of its ongoing theoretical development and the focus on the concept of "technological frame"-see below-as a hinge between the social shaping of technology and the technical shaping of society.) Artifacts are, so to speak, described through the eyes of the 1. members of relevant social groups. The interactions within and among relevant social groups constitute the different artifacts, some of which may be hidden within the same "thing." In that case, the "interpretative flexibility" of that "thing" is revealed by tracing the different meanings attributed to it by the various different relevant social groups. This demonstration of interpretative flexibility is a crucial step in arguing for the feasibility of any sociology of technology - it shows that neither an artifact's.identity nor its technical "working" or "nonworking" is an intrinsic property of the artifact 2. but is subject to social variables. The next step then is to describe how artifacts are indeed socially constructed, thus tracing the increasing (or sometimes decreasing) degrees of stability of that artifact. Pinch and Bijker (1984) use the high-wheeled bicycle of the 1870s as an example. The first step in their descriptive model is a sociological deconstruction of the artifact (by the analyst). In this case, this results in showing that "hidden within" the high wheeled Ordinary were at least two vastly different artifacts: the Unsafe Machine for women and older men, and the Macho Machine for "young men 2 of means and nerve." The second step is to trace the social construction of these artifacts (by the relevant social groups of actors). Several "closure mechanisms" can be identified that bring the interpretative flexibility to an end and start the process of stabilization of the artifact within the relevant social groups. The third step is to generalize beyond one case study to form a theory of sociotechnical ensembles. The concept of "technological frame" is then proposed to explain the development of heterogeneous sociotechnical ensembles, thus avoiding social reductionism (Bijker, 1987, 1992). A technological frame structures the interactions between the actors of a relevant social group. key characteristic of the "technological frame" is that it is applicable to all pelevant social groups-technicians and others alike. It is built up when interaction "around" a technology starts and continues. The early Deltaplan technology can, for instance, be said to have shaped the coastal engineers' technological frame, strongly influencing the choice for an ambitious "high-tech" solution for the Oosterschelde rather than merely heightening all dikes around the Oosterschelde basin. Existing practice does guide future practice, though without logical determination. The concept of "technological frame" forms a hinge in the analysis of sociotechnical ensembles; it is the way in which technology influences interaction and thus shapes specific cultures, but it also explains how a new technology is constructed by a combination of enabling and constraining interactions within relevant social groups in a specific way. 


\section{CONTROL AND INTERVENTION}

How do the approaches discussed in the previous sections deal with control and intervention? In most impact studies, technology is conceived of as a separate entity that follows a linear path. Technology is like a train running on a track that is fixed though not known in detail; one cannot hope to change the train's direction, only to check its speed and improve the safety of the crossings. Orthodox "technology assessment" as exemplified by the early work of the American Office of.Technology Assessment seeks to predict technelogical development and its impact on society and thus hopes to avoid some of its negative effects by "early warning." (See Leyten \& Smits, 1987, for a comparative review of different concepts of technology assessment.) Cost-benefit analyses are another example of control and intervention instruments that are based on this image of technology. Such an approach to technology implies a control dilemma (Collingridge, 1980)-either it is too early to foresee the implications of a new technology or it is too late to intervene because the technology has become so entrenched in society and culture that it cannot be changed anymore.

Linked to the social shaping and evolutionary views of technology are models of technology assessment developed in Sweden and the Netherlands. Leyten and Smits (1987) present a comparative study of the different notions of technology assessment in these places. (For more information about Sweden, see SFS, 1982; for more about the Dutch "constructive technology assessment" approach, see Daey Ouwens, Hoogstraten, Jelsma, Prakke, \& Rip, 1987, and Schot, 1991). Schwarz and Thompson (1990) examine "constructive technology assessment" on the basis of their cultural theory, which is an extension of the work of anthropologist Mary Douglas (e.g., 1970, 1982). In these models the possibility of continuously shaping and reshaping a technology during all its stages of development is recognized. A framework has been developed to encourage a positive interplay between the formal institutional technology assessments and the more informal technological evaluations carried out by other relevant social groups, such as consumers. In giving a role to these groups, it is recognized that technological development involves more than just engineers and politicians.

What form can control and intervention take in approaches that use sociotechnical ensembles as their unit of analysis? It is immediately clear that Collingridge's control dilemma now disappears. The seamless web character of technology and its pervasive socially constructed character indicate a multitude of opportunities to influence the development of technology (and society and so on) at all stages. But more studies of how this can be brought about are needed. Studies of ethical arguments made by proponents and opponents of a specific technology may be a valuable way of coming to grips 
with technology, as might be studies of technical norms and regulations. Ethnographic studies of accounting practices could document the process of shaping a technology by the management of an organization (MacKenzie, 1990b). So, for example, was it possible to "handle" the overrun on the Oosterschelde barrier budget by shifting some of the costs to other secondary projects, by redistributing the costs to other ministries, and by arguing that the costs were actually $20 \%$ lower than planned but that "the political decision to leave the Oosterschelde open" had caused the increase. Applied on a more macro-economic scale, the reclamation of flooded polders may not now seem as ludicrous as I suggested in the introduction. There is more to socioeconomic analysis than narrowly defined costs.

\section{CONCLUSION}

In this chapter I have tried to review the body of technology studies by presenting the various themes that are addressed by scholars in the STS community. The implicit thrust of the argument has been that "underneath" these themes, and relatively independent of their specificities, a general pattern can be recognized in which the study of technology and society has been developing. This pattern can, very schematically, be characterized as a sort of slow pendulum movement-a dampened oscillation.

Before the 1940s the social sciences did not pay much attention to the study of the detailed development of technical artifacts and society. (William Ogburn and Lewis Mumford were important exceptions; see Westrum, 1991, chap. 3, for a discussion of the "old" sociology of technology.) Except as an abstract concept, technology was almost nonexistent in the social sciences. The pendulum started to swing, and especially historians, some economists, and, later, philosophers and sociologists discovered technology. The swing went too far, however, and technology was viewed as an autonomous factor to which society had to bow. Technology was all important. With the rise of social shaping models, the pendulum swung back from this technological deterministconception. But again the swing went a little too far. The impact theme almost disappeared from view and technology seemed merely a social construct that could not appear in an obdurate, transformations-resisting, and soeiety shaping form. Recently the pendulum started to swing back again to redress this imbalance. Technology recaptured some of its obduracy without completely losing its socially shaped character. The swings are smaller now. Perhaps we should say that the pendulum is not moving anymore in a flat plane but moves in Foucaultian circles.

Technology studies should not stop at the conclusion that sociotechnical ensembles have emerged from the seamless web of technology and society. 
Research is called for in at least two directions. First, do we need a new theoretical framework to analyze the emergence, shaping, and development of ensembles? Simple technical or social reductionism will not do, but what will? (Woolgar, 1991b, addresses this question and argues for reflexively analyzing technology as a text. The focus, then, would not be on an analysis of different representations of technology but on the representational activity itself- - by actors as well as by the analyst. See also Pinch, 1993, and the chapters in this book by Callon and by Restivo.) Second, we need to return to some of the political questions that informed early STS studies. Technology studies as a field seems to have lost some of its direct relevance for the plethora of problems our societies at present face. The toll of academic respectability threatens to produce politico-cultural irrelevance.

\section{EPILOGUE}

Happily, in November 1991 the dikes did indeed resist the storm surge; in February 2053 there may be such a storm surge again. Small chances may combine into big effects. Will the Dutch dikes and flood barriers stand up to this? Will the global sea level rise as a result of the greenhouse effect and cause dangers that were not foreseen when the Delta level was fixed? Will the gradual lowering of Dutch land levels due to the exploitation of fossil gas supplies add more to this than currently expected? Will there be lights on during that stormy February night in 2053? How much will the Zeeland inhabitants then trust the Deltaplan technology?

The Deltaplan project was closely and critically followed by various relevant social groups-this technology certainly was not developed in isolation. The general public probably knows more about these coastal defense technologies than about any other modern technological system. It seems to make perfect sense, for example, to have a parliamentary discussion about the operating criteria of the Oosterschelde barrier. Public interestand insight into the sociotechnical system are such that the recently published evaluation of the first 5 years of operation will be discussed intensively in public hearings before leading to a decision about operational criteria of the barrier: At what water levels should the doors be closed? What tide regime should be realized during these closures? The old parties take position: Environmentalists propose to increase the level so that the barrier will be closed less frequently; regional political authorities will probably opt for a lower norm for greater safety.

Can the type of technology studies discussed in this chapter contribute to the safety of the Netherlands in 2053 ? Certainly not in the form of presenting straightforward instruments of policymaking or technology assessment. 
Technology and society are entangled in much too complex an ensemble to hope for context-independent instruments or recipes. If technology studies can be expected to contribute, it will more likely be in the spirit of the ideals of the Enlightenment-to provide insight into fundamental processes underpinning the development of societies and technologies. An analysis of how literature and art mirror technological and societal developments and thereby contribute to their mutual shaping could also be a fruitful entrance for such enlightening studies (e.g., Hughes, 1989a; Marx, 1964; Williams, 1990). There are no privileged actors anymore-neither engineers, nor managers, nor policymakers. All contribute, knowingly or unknowingly, to the shaping of sociotechnology. Of course, we can choose to develop organizational and regulatory frameworks that make more explicit the involvement those specific relevant social groups have (see also Jasanoff, 1990a, who investigates the regulatory process from a similar perspective). It is encouraging that the public can participate in the decision process to set the operation procedures of the Oosterschelde flood barrier. A decade ago most people probably would have agreed that democratic control and "high-tech" systems are a contradictio in terminis. It was argued (e.g., Winner, 1980) that nuclear energy would only be possible in a centralized "police state." Democratic energy distribution technology then was synonymous with decentralized, small-scale energy systems. Mathews (1989a, 1989b) addresses problems of democratic control in a social-democratic system by taking recent technology studies into account. We have to continue to study sociotechnology in all its heterogeneity. We can only hope to contribute to the democratic control of technology by continuing to pry open the black box of technology and to monitor the evolution of sociotechnical systems. 